Article

\title{
An Insight into the Anxiolytic and Antidepressant-Like Proprieties of Carum carvi L. and Their Association with Its Antioxidant Activity
}

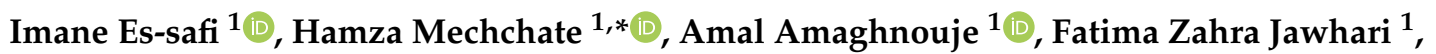

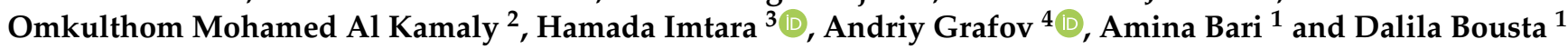 \\ 1 Laboratory of Biotechnology, Environment, Agrifood, and Health, University of Sidi Mohamed Ben Abdellah, \\ FSDM-Fez 30050, Morocco; Imane.essafi1@usmba.ac.ma (I.E.-s.); Amal.amaghnouje@usmba.ac.ma (A.A.); \\ Fatimazahra.jawhari@usmba.ac.ma (F.Z.J.); amina.bari@usmba.ac.ma (A.B.); \\ dalila.bousta@usmba.ac.ma (D.B.) \\ 2 Department of Pharmaceutical Sciences, College of Pharmacy, Princess Nourah Bint Abdulrahman University, \\ Riyadh 11564, Saudi Arabia; omalkmali@pnu.edu.sa \\ 3 Faculty of Arts and Sciences, Arab American University Palestine, Jenin 240, Palestine; \\ hamada.imtara@aaup.edu \\ 4 Department of Chemistry, University of Helsinki, 00100 Helsinki, Finland; andriy.grafov@helsinki.fi \\ * Correspondence: Hamza.mechchate@usmba.ac.ma; Tel.: +212-602-083-601
}

\section{check for} updates

Citation: Es-safi, I.; Mechchate, H.; Amaghnouje, A.; Jawhari, F.Z.; Al Kamaly, O.M.; Imtara, H.; Grafov, A.; Bari, A.; Bousta, D. An Insight into the Anxiolytic and Antidepressant -Like Proprieties of Carum carvi L. and Their Association with Its Antioxidant Activity. Life 2021, 11, 207. https://doi.org/10.3390/ life11030207

Academic Editor: Raffaele Capasso

Received: 27 January 2021

Accepted: 26 February 2021

Published: 5 March 2021

Publisher's Note: MDPI stays neutral with regard to jurisdictional claims in published maps and institutional affiliations.

Copyright: (c) 2021 by the authors. Licensee MDPI, Basel, Switzerland. This article is an open access article distributed under the terms and conditions of the Creative Commons Attribution (CC BY) license (https:/ / creativecommons.org/licenses/by/ $4.0 /)$.
Abstract: Depression and anxiety are widespread illnesses whose consequences on patients' social and professional lives are becoming ever more dangerous and severe. The study's objective is to explore the antidepressant-like and anxiolytic activity of the polyphenolic extract of Carum carvi L. as well as its antioxidant power as they were recently associated. The predictive antidepressant activity was evaluated using the forced swimming and tail suspension test in mice, a preclinical behavioral model widely used to determine the efficacy of antidepressant drugs. As for anxiolyticlike activity, two models were used, namely the light/dark chamber test to measure the animal's degree of anxiety and the open field test to evaluate both anxiolytic and locomotor activity. The tests results indicate a remarkable antidepressant and anxiolytic-like effect after oral administration of the polyphenolic fraction of C. carvi and interesting antioxidant property. In the extract it has been confirmed the presence of 6 molecules belonging to polyphenols, identified with HPLC analysis. This study confirms and encourages the traditional use of the extract and appeals to further studies to understand its action mechanism.

Keywords: antidepressant-like; anxiolytic; antioxidant; Carum carvi L.; polyphenols; tail suspension test; light-dark chamber test; forced swim test; open field test; DPPH test; FRAP test

\section{Introduction}

The 21st century represents a radical change for the human being in terms of lifestyles, rhythms, and demands. People are then subjected to new situations that they must face. As a result, many of them complain of anxiety, depression, or stress [1]. Alternative treatments currently have an important place in the therapeutic strategy [2].

The development of plant-derived anxiolytic and antidepressant drugs involves several investigations of ethnopharmacological, phytochemical, and pharmacological order. Moreover, the selection of a suitable plant for a pharmacological study is one of the most important steps and the various indices that should be taken into consideration include conventional application, chemical composition and toxicity [3].

About $50 \%$ of the therapeutic agents currently used come from natural sources, while less than $10 \%$ of plant species have been examined for their biological properties. These percentages indicate that new therapeutic discoveries can still be elucidated on medicinal plants [4]. 
Aromatic plants form a fundamental natural richness, for which valorization in its turn needs a perfect understanding of the physical and chemical properties which can be scientifically enhanced [5]. The properties of plants depend on the presence of various bioactive molecules belonging to different chemical families.

Morocco, by its geographical situation, offers rich and diverse vegetation. It has about 4200 species, most of which are not exploited [6]. Carum carvi L., one of the Apiaceae family species, and considered to be one of the most used medicinal plants in conventional medicine, has been selected for this study [6]. The genus Carum is among the most popular genera in the Apiaceae family and has about 20-30 species from Europe, North Africa, and Asia [7]. This genus's best-known species is Carum carvi L., Caraway seeds have been traditionally used as a condiment or spice thanks to their pleasant flavor [2].

It has also been used as an important source of spices and extracts with high antioxidant and antimicrobial power. This plant was also used to extract carvone, which is one of the main components of caraway essential oil, which inhibits the germination of stored potatoes and onions [8].

Many studies are currently interested in medicinal plants for their richness in secondary metabolites such as polyphenols, flavonoids, tannins, etc. They have a panacea of therapeutic virtues, including antioxidant and antimicrobial activities, anti-inflammatory, anticancer, and many others [9]. In this context, our work aims to evaluate the pharmacological activity of phenolic extracts of Carum carvi L. (PCC) in experimentally-induced anxiety and depression in mice as it's been reported to be traditionally used for this purpose [10] and its correlation with the plant antioxidant properties using the DPPH (2,2-Diphenyl-1-picrylhydrazyl) and FRAP (Ferric reducing antioxidant power) test.

\section{Results and Discussion}

\subsection{Extract Biochemical Analysis}

Figure 1 shows the HPLC (High-performance liquid chromatography) analysis chromatogram, and Table 1 represents the details of the main compounds. Almost all of the components identified were investigated for their anxiolytic and antidepressant-like effects, such as gallic acid [11], quercetin [12], catechin [13], myricetin [14], and caffeic acid [15].

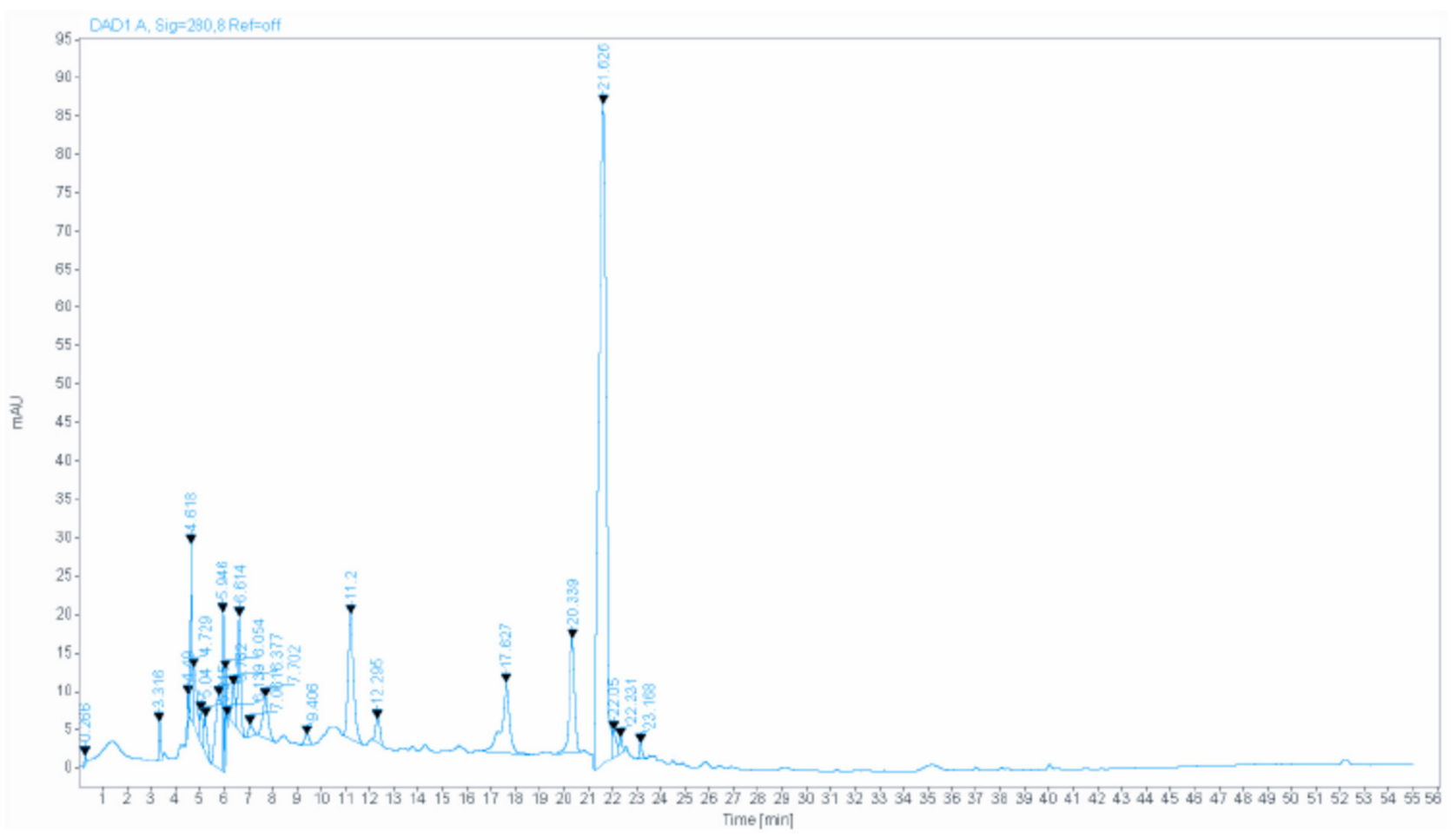

Figure 1. The HPLC chromatogram of PCC. 
Table 1. The HPLC result of PCC.

\begin{tabular}{ccccc}
\hline Extract & Molecules & Retention Time & $\begin{array}{c}\text { Retention Time } \\
\text { (Standard) }\end{array}$ & Concentration $(\mu \mathbf{g} / \mathbf{m L})$ \\
\hline \multirow{6}{*}{ PCC } & Ferulic acid & 21.020 & 21.039 & 27.70 \\
& Gallic acid & 6.614 & 6.645 & 9.17 \\
& Myricetin & 22.231 & 22.278 & 7.50 \\
& Catechin & 12.295 & 12.777 & 6.80 \\
& Caffeic acid & 17.627 & 17.336 & 6.77 \\
& Quercetin & 23.168 & 23.350 & 4.77 \\
\hline
\end{tabular}

Ferrulic acid antidepressant-like activity was assassed in different studies relating it to its antioxidant [16] and anti-inflammatory proprieties [17], with a strong promoting of metabolism energy, an increased neurotrophic, ATP and catecholamine levels and decreased level of glycogen in the limbic system [18]. This compound also demonstrated an anxiolytic effect in alcohol withdrawal induced anxiety in mice [19] suggesting it potential mecanism of action the partial involvement of the NMDA (N-methyl-D-aspartate) receptor [20].

\subsection{Evaluation of the Anxiolytic Activity of the Polyphenolic Fraction of C. carvi \\ 2.2.1. Light and Dark Room}

According to our results (Figure 2), bromazepam at $1 \mathrm{mg} / \mathrm{kg}$ significantly increased the time spent by the mice in the light compartment $(122.2 \pm 3.760$ on day $1 ; 146.6 \pm 1.068$ on day 21) compared to the control group (63.2 \pm 3.367 on day $1 ; 75.8 \pm 4.352$ on day 21). A significant increase in the time spent in the light compartment was observed with the administration of 50 and $100 \mathrm{mg} / \mathrm{kg}$ PCC of $(85.4 \pm 9.626$ on day $1 ; 269 \pm 9.055$ on day 21) (94 \pm 6.107 on day $1 ; 265 \pm 7.21$ on day 21$)$ respectively compared to control.

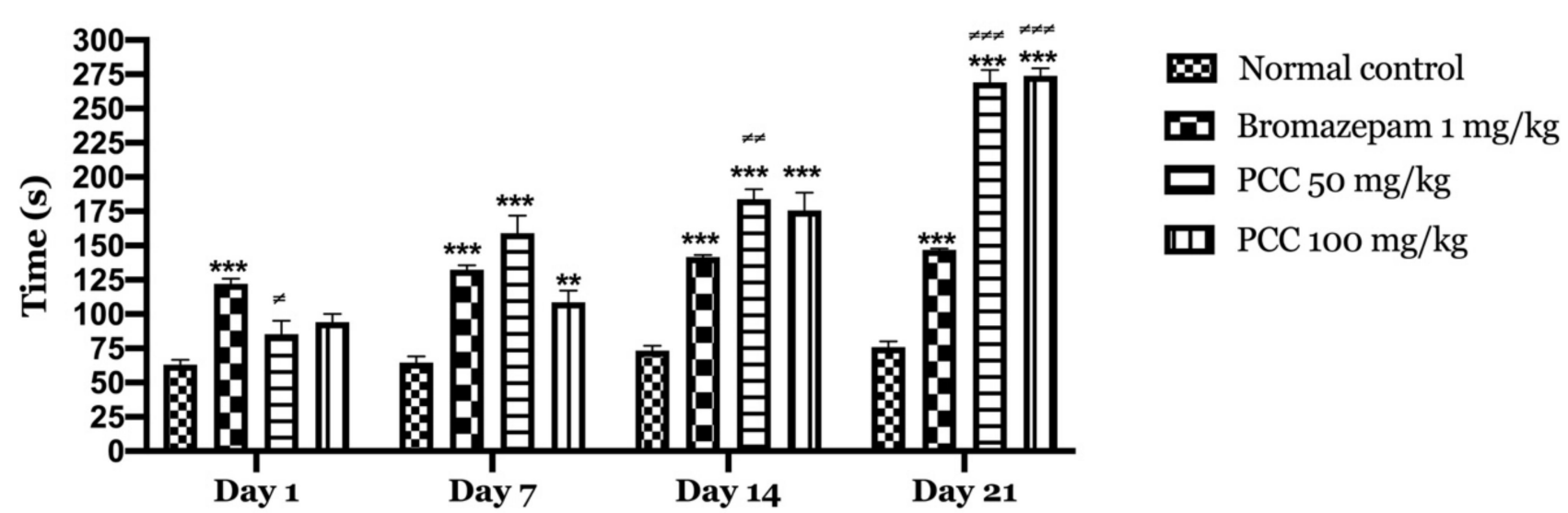

Figure 2. Time spent in the bright room in the light and dark room test. Time spent in the bright room in the light and dark room test. Data are displayed as mean \pm SEM. A two-way analysis of variance (ANOVA) for repeated measures with Dunnett post hoc test were used to analyse the data. *: Represent the comparison of the different groups with the control $\left({ }^{* *} p<0.001,{ }^{* *} p<0.01\right) \neq$ : Represent the comparison of the different groups with bromazepam $(\neq \neq \neq p<0.001$, $\neq \neq p<0.01, \neq p<0.05)$.

Figure 3 shows that the transitions of mice treated with PCC at the $50 \mathrm{mg} / \mathrm{kg}$ dose and those treated at the $100 \mathrm{mg} / \mathrm{kg}$ dose increase significantly $(2.00 \pm 0.707$ on day 1 ; $11.40 \pm 1.166$ on day 21$)(3.00 \pm 0.548$ on day $1 ; 16.00 \pm 0.430$ on day 21$)$ respectively compared to the control $(9.80 \pm 1.241$ on day $1 ; 10.00 \pm 0.837$ on day 21$)$. A significant increase in transitions in treated mice with bromazepam $1 \mathrm{mg} / \mathrm{kg}(13.800 \pm 0.735$ on day 1 ; $12.00 \pm 0.949$ on day 21) was noted compared to control. 


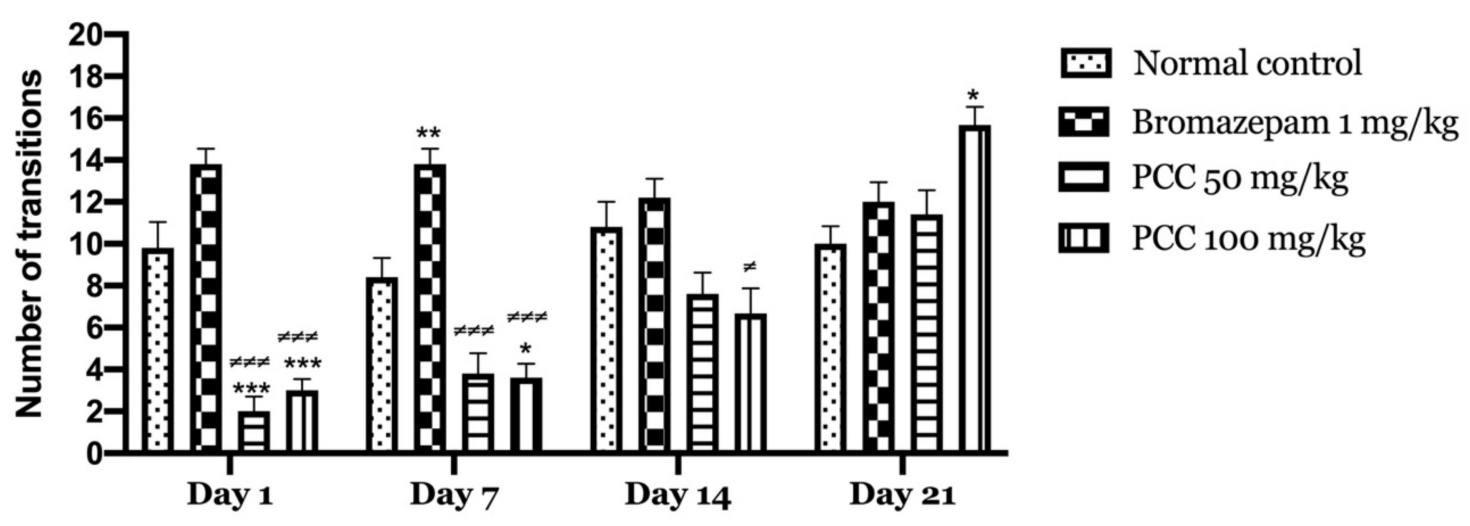

Figure 3. Number of transitions in the light and dark room test. Data are displayed as mean \pm SEM. A two-way analysis of variance (ANOVA) for repeated measures with Dunnett post hoc test were used to analyse the data. ${ }^{*}$ : Represent the comparison of the different groups with the control $\left({ }^{* * *} p<0.001,{ }^{* *} p<0.01,{ }^{*} p<0.05\right) \neq$ : Represent the comparison of the different groups with bromazepam $(\neq \neq \neq p<0.001, \neq p<0.05)$.

We noticed an increase in the time spent in the lighted chamber in mice treated with the PCC extract compared to the control. Besides, we recorded the increase in transition time compared to that of the control mice. This highlights the anxiolytic-like profile of the polyphenolic fraction of caraway.

To measure the anxiety level in mice in the light \& dark room test, two parameters were used: the time spent in the dark room, which is proportional to the level of anxiety, and the number of transitions from one compartment to the other which is relatively proportional to the level of anxiolysis [21].

Based on the fact that an anxiolytic compound increases the time spent by the animal in the illuminated area, we assume that a mouse spending more time in the dark zone shows a higher anxiety level. An anxious animal will therefore spend more time in the dark area.

According to our results, a dose of $50 \mathrm{mg} / \mathrm{kg}$ of $C$. carvi polyphenolic extract exerts a significant anxiolytic-like effect. When the dose is increased to $100 \mathrm{mg} / \mathrm{kg}$, we note that this effect is attenuated. This could be explained by sedation induced by this dose. Other studies have used the light/dark chamber test to evaluate the anxiolytic activity of the hydro-ethanolic extract of coriander at doses of 50,100, and $200 \mathrm{mg} / \mathrm{kg}$, the study results suggest that the extract produced an anxiolytic effect at 100 and $200 \mathrm{mg} / \mathrm{kg}$ [22].

A correlation between oxidative stress and mood disorders has been reported in recent studies [23,24] and psychological stress [25,26], This opens up new possibilities for anxiety and depression treatment and/or prevention, with the possible use of antioxidants. Desrumaux et al. [27] found that vitamin E deficiency in mice brains substantially improved the core markers of oxidative stress and anxiety-provoking activity in mice. Similarly, mice fed with vitamin $C$ have recently demonstrated that this compound has an antidepressant effect in the tail suspension test [28]. The powerful antioxidant potential of polyphenols is well known [29] and their utilization could be an interesting approach to treat anxiety and depression. The anxiolytic activity of the polyphenolic fraction (PCC) can be attributed to our extract's antioxidant activity. Numerous studies have shown that polyphenols are interesting natural antioxidant substances that can exert pharmacological effects on the central nervous system (CNS) [30,31]. Polyphenols exert partial agonist properties at benzodiazepine receptors, which gives them an impressive anxiolytic power [32].

\subsubsection{Open Field}

Our results show that downtime is significantly reduced in treated mice (PCC) compared to bromazepam and control group. Figure 4 shows that there is an increase in the number of tiles crossed in the PCC-treated groups at $50 \mathrm{mg} / \mathrm{kg}$ and $100 \mathrm{mg} / \mathrm{kg}$ of $(100.8 \pm 12.64 \mathrm{on}$ 
day $1 ; 161.25 \pm 15.705$ on day 21 ) ( $34 \pm 12.07$ on day $1 ; 167.25 \pm 10.39$ on day 21$)$ respectively compared to the control (148.4 \pm 3.44 on day $1 ; 167.25 \pm 10.39$ on day 21$)$.

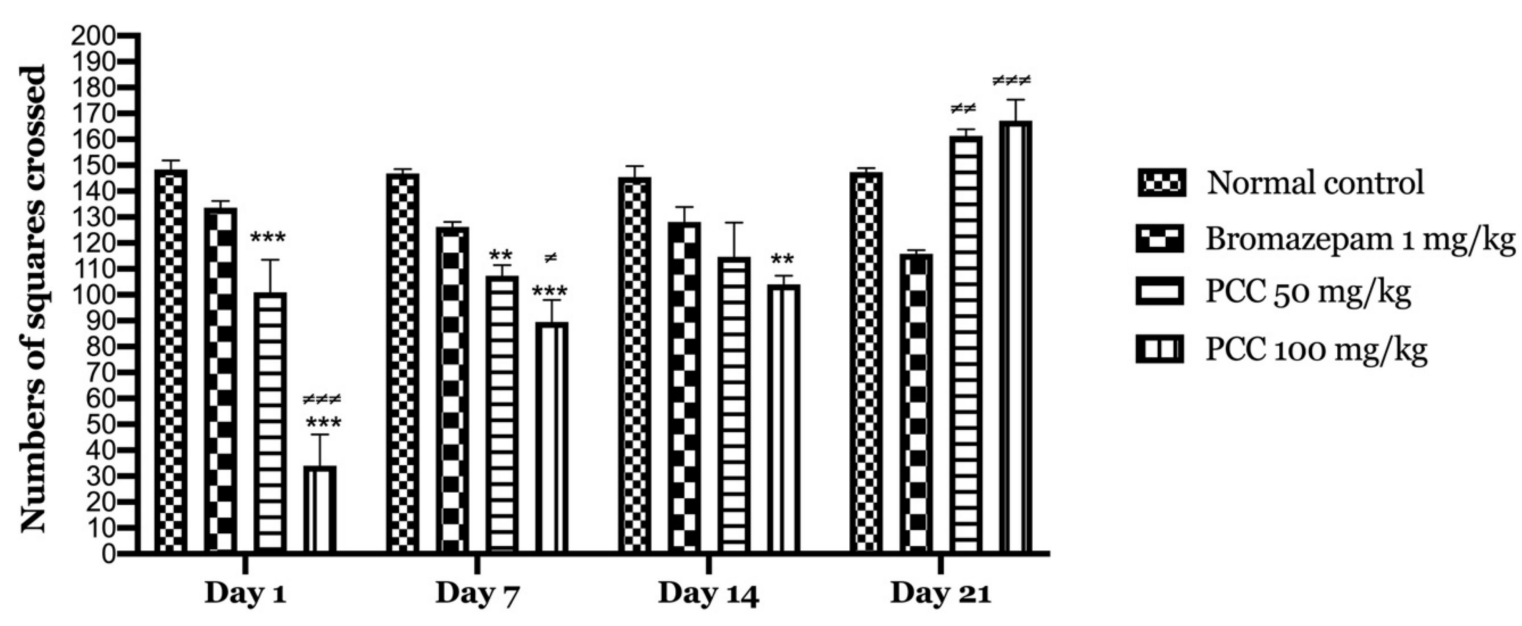

Figure 4. Numbers of squares crossed in the open field test. Data are displayed as mean \pm SEM. A two-way analysis of variance (ANOVA) for repeated measures with Dunnett post hoc test were used to analyse the data. *: Represent the comparison of the different groups with the control $\left.{ }^{* * *} p<0.001,{ }^{* *} p<0.01\right) \neq$ : Represent the comparison of the different groups with bromazepam $(\neq \neq \neq p<0.001, \neq \neq p<0.01, \neq p<0.05)$.

We also find that the time spent in the center is significantly increased in treated mice (PCC) at $50 \mathrm{mg} / \mathrm{kg}$ and $100 \mathrm{mg} / \mathrm{kg}$ of $(15.8 \pm 2.551$ on day $1 ; 34 \pm 2.121$ on day 21) ( $3 \pm 0.837$ on day $1 ; 27.25 \pm 1.652$ on day 21$)$ respectively compared to the control $(16.8 \pm 1.241$ on day $1 ; 17.6 \pm 1.077$ on day 21$)$ (Figure 5$)$.

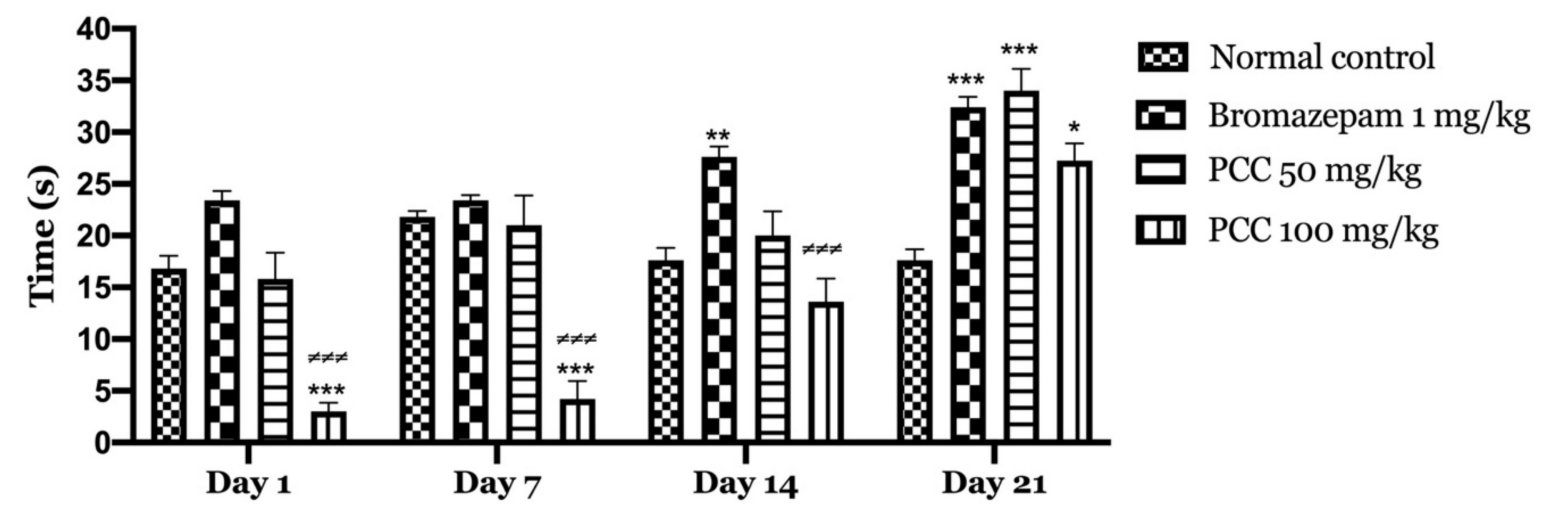

Figure 5. Time spent at the center in the open field test. Data are displayed as mean \pm SEM. A two-way analysis of variance (ANOVA) for repeated measures with Dunnett post hoc test were used to analyse the data. *: Represent the comparison of the different groups with the control $\left(* * *<0.001,{ }^{* *} p<0.01, * p<0.05\right) \neq$ Represent the comparison of the different groups with bromazepam $(\neq \neq \neq p<0.001)$.

We noted a significant increase in locomotion in the central part of mice treated with PCC extract at $50 \mathrm{mg} / \mathrm{kg}$ compared to the control. In addition, we recorded a decrease in locomotion in the peripheral part. Immobility time was decreased in mice treated with $50 \mathrm{mg} / \mathrm{kg}$ compared to the control mice.

In our study, we used the open-field test to assess anxiety in mice. Mice are nocturnal animals, accustomed to a dark and confined environment. However, this test's center is open and bright, so it is the most anxious area for the animal in opposition to the periphery of the field that presents the least stressful area for the animal. As a result, control animals tend to spend more time in the periphery rather than in the center, which is considered the most anxiety-inducing zone [33]. 
An animal that is very active in the periphery and not very active in the center of the open field is considered to have a high anxiety level [34]. The variables measured to assess the animal's anxiety level are: (i) the distribution of activity in the periphery and in the center, (ii) the time spent in each zone (periphery and center), indicate the anxiety level of the mice, and (iii) the number of recoveries indicating the level of its exploratory activity (habituation). Locomotion in the open field was evaluated by measuring the locomotion index in the peripheral part as well as in the central part as a function of time (total number of tiles).

Polyphenolic extract at $50 \mathrm{mg} / \mathrm{kg}$ and $100 \mathrm{mg} / \mathrm{kg}$ produced an anxiolytic effect due to the significant increase in time spent in the center and the number of tiles crossed. A study was performed by Mahendra et al. on the hydro-ethanolic extract of Coriandrum sativum at $50,100,200 \mathrm{mg} / \mathrm{kg}$ showed that the dose of $200 \mathrm{mg} / \mathrm{kg}$ has an anxiolytic-like activity. The latter is probably associated with its flavonoid content. The mechanism of action by which C. sativum exhibits anxiolytic-like activity may be similar to that of diazepam (which acts via the (GABA) receptor complex), because flavonoids and diazepam are structurally identical. The effects of flavonoids as anxiolytics have been observed in many plant species used in medicine [22].

\subsection{Evaluation of the Antidepressant Activity of the Polyphenolic Fraction of C. carvi}

\subsubsection{Forced Swimming}

Figure 6 shows the variation in immobility times, in control mice and mice treated with the polyphenolic extract of caraway at 50 and $100 \mathrm{mg} / \mathrm{kg}$ undergoing the forced swimming test. In our results, we found that the immobility time decreased significantly in mice treated with PCC at 50 and $100 \mathrm{mg} / \mathrm{kg}$ of $(81 \pm 3.055$ on day $1 ; 0 \pm 0.00$ on day 21) $(48.66 \pm 4.631$ on day $1 ; 0 \pm 0.00$ on day 21$)$ compared to control mice (149.66 \pm 2.603 on day $1 ; 172.33 \pm 8.686$ on day 21$)$.

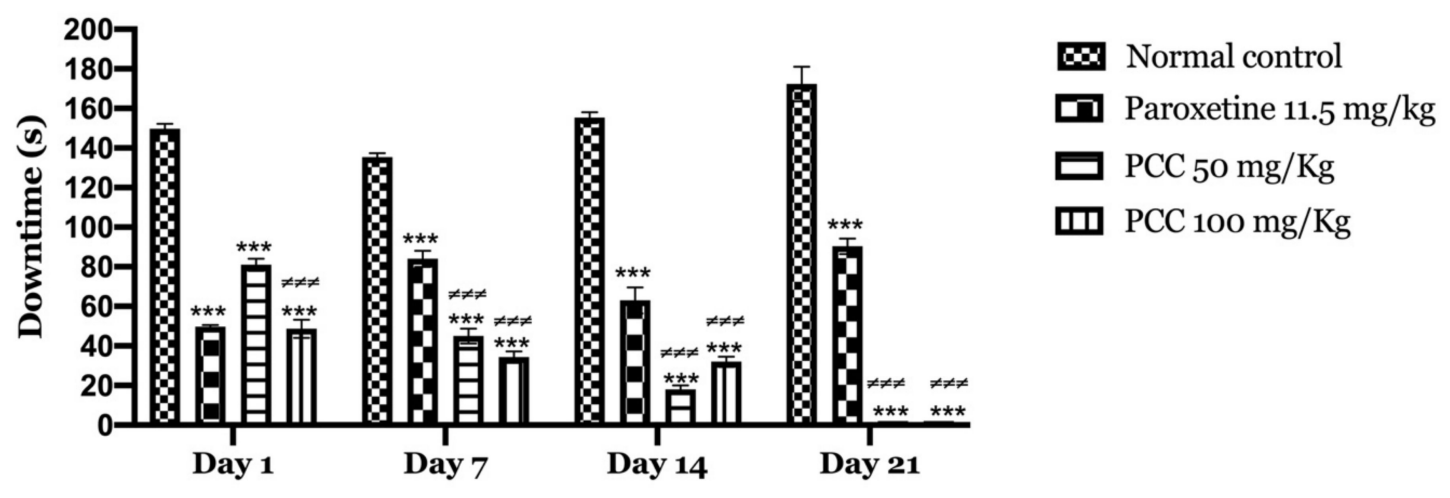

Figure 6. Downtime in forced swimming test. Data are displayed as mean \pm SEM. A two-way analysis of variance (ANOVA) for repeated measures with Dunnett post hoc test were used to analyse the data. *: Represent the comparison of the different groups with the control $(* * *<0.001) \neq$ Represent the comparison of the different groups with paroxetine $(\neq \neq \neq p<0.001)$.

The forced swimming test is validated as an experimental approach to assess the potential efficacy of antidepressants in rodents and represents an aversive stressful situation from which the rat or mouse cannot escape, and produces immobility, i.e., behavioral despair [35]. Our results indicate an antidepressant effect of the polyphenolic extract of $C$. carvi, translated by a decrease in immobility time and with an increase in active behaviors, such as swimming and climbing. There is an excellent correlation between the predicted antidepressant activity in the FST assay and the clinically revealed antidepressant profile since $94 \%$ of the experimentally predicted antidepressant substances were future antidepressant molecules. This decrease in immobility may favor either an increase in swimming time or an increase in climbing time. Antidepressants that produce a predominantly noradrenergic and/or dopaminergic elevation reduce immobility by increasing the climbing time [36]. In contrast, those that reduce immobility by increasing swimming involve more central serotonin neurotransmission [37]. 
By comparing our results with those in the literature, researchers used the forced swimming test to evaluate the antidepressant activity of several plant extracts, for example, the methanolic extract of Foeniculum vulgare of the Apiaceae family. The results of this work showed that oral administration of $F$. vulgare extract produced antidepressant activity at a dose of 250 and $500 \mathrm{mg} / \mathrm{kg}$ in a dose-dependent manner compared to the control group [38]. Other studies on aqueous and ethanol extract of Pimpinella anisum of the Apiaceae family have shown that P. anisum has antidepressant activity at doses of 100 and $200 \mathrm{mg} / \mathrm{kg}$ in the forced swimming test [39].

The antioxidant activity of the polyphenolic extract of Carum carvi can be linked to PCC's antidepressant activity. Studies have shown that polyphenols have similar effects to antidepressants [30,31] at lower doses than reference antidepressants. They can be used to stabilize the mood of depressed patients.

\subsubsection{The Tail Suspension Test}

The polyphenolic extract of Carum Carvi L. showed an average decrease in immobility time on the first day of treatment, but decreased significantly after 7, 14 and 21 days of treatment.

The treated groups showed a considerable reduction in immobility time that was almost similar to that of standard paroxetine.

On day 1 of the test, the immobility time in the paroxetine, PCC $50 \mathrm{mg} / \mathrm{kg}$ and PCC $100 \mathrm{mg} / \mathrm{kg}$ groups were $99 \pm 2.06,123.8 \pm 4.10$ and $112 \pm 2.81 \mathrm{~s}$ respectively, which was significant compared to the control group in which the immobility time was $161.67 \pm 5.96 \mathrm{~s}$.

On day 7 of the test, the immobility time in the paroxetine, PCC $50 \mathrm{mg} / \mathrm{kg}$ and PCC $100 \mathrm{mg} / \mathrm{kg}$ groups was $101.67 \pm 2.62,103.16 \pm 2.45$ and $100.33 \pm 2.56 \mathrm{~s}$ respectively, which was significantly reduced compared to the control group in which the downtime time was $147.16 \pm 4.95 \mathrm{~s}$.

On day 14 of the test, the immobility time in the paroxetine, PCC $50 \mathrm{mg} / \mathrm{kg}$ and PCC $100 \mathrm{mg} / \mathrm{kg}$ groups was $92.33 \pm 2.17,102.33 \pm 1.33$ and $95.5 \pm 4.04 \mathrm{~s}$, respectively, which was also significantly reduced compared to the control (198.16 $\pm 5.95 \mathrm{~s})$.

Similarly, on day 21 of the test, the immobility time in the paroxetine, PCC $50 \mathrm{mg} / \mathrm{kg}$ and PCC $100 \mathrm{mg} / \mathrm{kg}$ groups was $102 \pm 4.45,97.83 \pm 4.19$ and $83.83 \pm 2.73 \mathrm{~s}$, respectively, compared to $145.5 \pm 1.99 \mathrm{~s}$ noted for the control group (Figure 7).

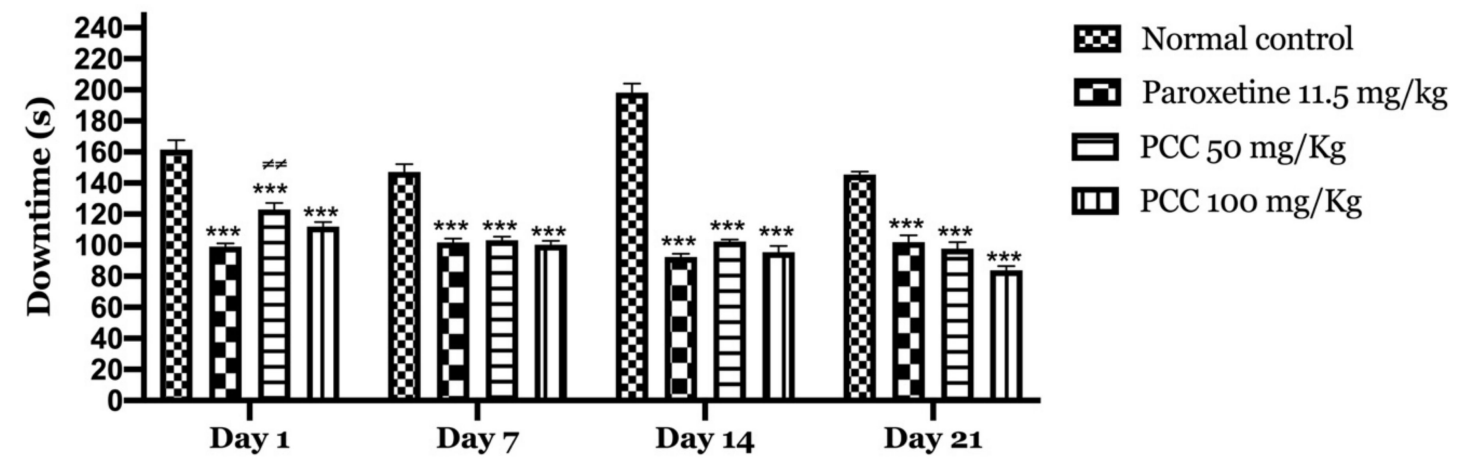

Figure 7. Downtime of the animals in the tail suspension test. Data are displayed as mean \pm SEM. A two-way analysis of variance (ANOVA) for repeated measures with Dunnett post hoc test were used to analyse the data. *: Represent the comparison of the different groups with the control $\left({ }^{* * *} p<0.001\right) \neq$ : Represent the comparison of the different groups with paroxetine $(\neq \neq p<0.01)$.

\subsection{Antioxidant Activity}

A compound's antioxidant function refers to its capacity to prevent oxidation. Several aromatic plant extracts are considered an excellent source of antioxidant molecules. In this context, we evaluated the antioxidant activity of polyphenolic extract of caraway (seed), using DPPH and FRAP methods. 


\subsubsection{DPPH (2,2-Diphenyl-1-picrylhydrazyl) Antioxidant Activity}

The DPPH method is generally the most widely used method for rapid and direct assessment of antioxidant activity because of the free-radical form stability of DPPH and the simplicity of analysis. The polyphenolic extract's antioxidant activity was evaluated using a methanolic solution of DPPH $(0.004 \%)$. A dark purple color with optimum absorption at $517 \mathrm{~nm}$ is seen in the freshly prepared DPPH solution. When an antioxidant is active in the medium, this color normally disappears. Thus, DPPH free radicals can be neutralized by antioxidant molecules (by supplying hydrogen atoms or by contributing electrons) and transformed into a yellow-colored substance, resulting in a decrease in absorption.

Figure 8 illustrates the evolution of antioxidant activity (\%) of the polyphenolic extract studied, as well as the BHT (Butylated hydroxytoluene) used as a positive control. It seems that the percentage of free radical neutralization is proportional to the extract concentration.

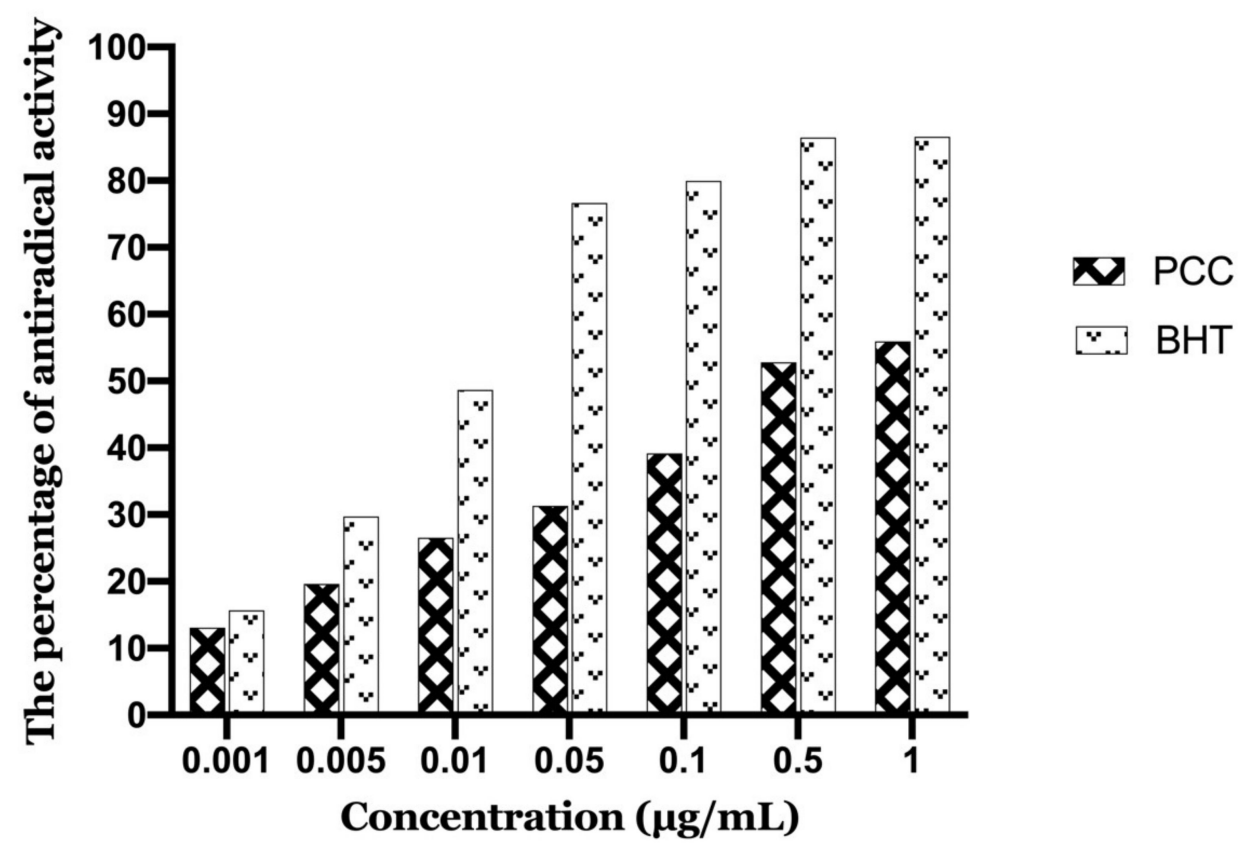

Figure 8. Antioxidant activity as a function of caraway polyphenol concentrations.

The polyphenolic extract of caraway exerts antioxidant activity over the entire range of concentrations studied. Indeed, the concentration of $1 \mu \mathrm{g} / \mathrm{mL}$ inhibits $55.94 \%$ of DPPH. The concentration that provides $50 \%$ inhibition (IC50) was calculated from the calibration curve (PCC and BHT are $0.267 \mu \mathrm{g} / \mathrm{mL}$ and $0.024 \mu \mathrm{g} / \mathrm{mL}$, respectively). Also, the lower the IC50 values, the stronger the antioxidant power. The IC50 value calculated for our PCC extract confirmed the reactivity of the sample to DPPH.

Compared to the standard antioxidant BHT $(\mathrm{IC} 50=0.024 \mu \mathrm{g} / \mathrm{mL})$ the PCC extract was less active. In general, for the plant studied, we have an interesting antioxidant activity (IC50 $=0.267 \mu \mathrm{g} / \mathrm{mL})$.

\subsubsection{FRAP Method}

It is a method of measuring our extract substances' ability to reduce ferric iron $\left(\mathrm{Fe}^{3+}\right)$ to ferrous iron $\left(\mathrm{Fe}^{2+}\right)$. It is a fast, easy and reproducible technique [40].

The reducing capacity of a compound can serve as a significant indicator of its potential antioxidant activity. Previous work has indicated that there is a direct relationship between antioxidant activities and the reducing power of components in some plants [41]. An increase in absorbance corresponds to an increase in the tested extract's reducing ability [42].

In our work, we tested by the FRAP method the polyphenolic extract of caraway with the positive control (BHT), whose absorbance was measured under the same condi- 
tions as the samples. The results obtained for iron reduction allowed us to draw curves $(\mathrm{DO}=\mathrm{f}($ concentration $))$ for each extract.

Figure 9 shows the reducing power of PCC and BHT. It can be seen that the iron reduction capacity is proportional to the increase of the PCC concentration. The extract has a dose-dependent activity. However, PCC has a lower reducing power than BHT. We note that BHT has an important activity to reduce iron with a maximum optical density of 0.87 at a concentration of $1 \mathrm{mg} / \mathrm{mL}$ compared to PCC, which presented an OD of about 0.67 for the same concentration.

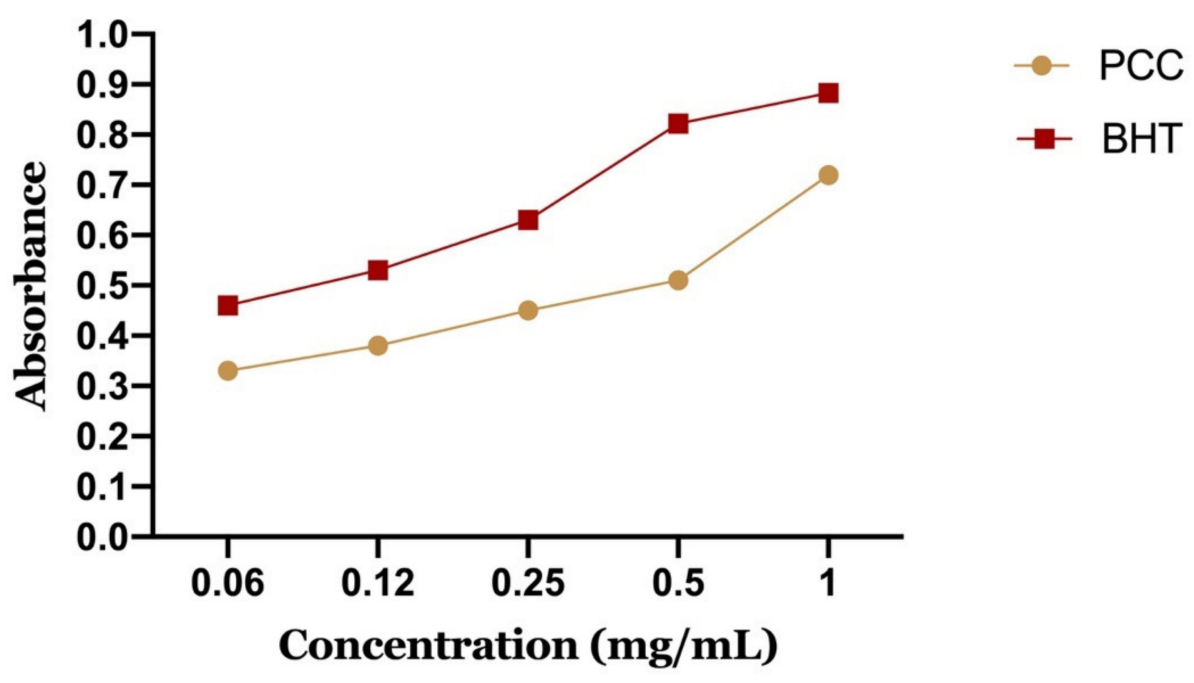

Figure 9. Reducing power of the polyphenolic fraction of Carum Carvi L.

The $50 \%$ effective concentration (EC-50) was calculated from the calibration curve, which corresponds to the concentration of antioxidants required to obtain an absorbance of $0.5 \mathrm{~nm}$. PCC represents a $50 \%$ effective concentration of $0.56 \mathrm{mg} / \mathrm{mL}$ and BHT of $0.09 \mathrm{mg} / \mathrm{mL}$.

\section{Materials and Methods}

\subsection{Extraction}

Carum carvi L. seeds were collected from the region of Taounate (Fez, Morocco). The identification and authentication (BPRN15) was precisely done by a botanist, Professor Amina Bari at the laboratory of LBEAS, FSDM.

The vegetal material is delipidated in a $500 \mathrm{~mL}$ bottle, by adding $20 \mathrm{~g}$ of caraway powder to $200 \mathrm{~mL}$ of hexane (maceration for $1 \mathrm{~h}$ repeated three times). After filtration and drying, the residue obtained was re-extracted with $70 \%$ methanol in an ultrasound-assisted extraction apparatus (sonicator) for $40 \mathrm{~min}$ at a frequency of $35 \mathrm{kHz}$. After this, the extract was filtered using Whatman filter paper No. 5. The filtrate was dried and concentrated using a rotary evaporator.

The dry extract was diluted in distilled water and then washed out two times with chloroform and dichloromethane (v:v) to obtain a cleaner solution of the extract by getting rid of the left pigments and the mannitol. In this last step, the polyphenols found were concentrated and preserved for further use (final yield 2.7\%).

\subsection{Animals}

Swiss albino mice were provided from the laboratory animal house (LBEAS) at the FSDM (Fez, Morocco). They were placed in groups of 5 in standard cages and subjected to 14 days adaptation period prior to the beginning of any experiment. During this time the animals had unrestricted access to food and water and were held at a steady temperature of $23 \pm 2{ }^{\circ} \mathrm{C}$ and a $12 / 12 \mathrm{~h} \mathrm{light/dark} \mathrm{cycle.}$

Two plant extract doses (50 and $100 \mathrm{mg} / \mathrm{kg}$ ) were tested. Bromazepam $(1 \mathrm{mg} / \mathrm{kg})$ has been used as a positive control for anxiety tests, and paroxetine $(11.5 \mathrm{mg} / \mathrm{kg})$ for depression 
tests. The groups underwent 21 days of sub-acute treatment and were evaluated on the 1st, 7th, 14th, and 21st days [43]. The treatments were delivered orally to the animals by intragastric gavage using a gavage needle tipped with a stainless steel bulb to inject it into the stomach. The protocol (07\#12/2019/LBEAS) was accepted by the institutional animal ethics committee.

\subsection{Antidepressant Activity}

Predictive Test for Depression in Animals: Porsolt Test or Forced Swimming Test

The forced swimming test or Porsolt's model [44] is a pharmacological test predictive of a molecule's antidepressant efficacy. This test is widely used to highlight the potential antidepressant properties of new molecules. It consists of forcing animals to swim in a closed enclosure at the height of $12 \mathrm{~cm}$ of water with no possibility of escape. This depth does not allow the animal to put its hind legs on the bottom of the cylinder. After a few minutes, the time spent swimming is reduced in favor of the immobility behavior, i.e., the animal floats passively, making only the movements necessary to keep its head out of the water. Immobility time is an indicator of the animal's pseudo-depressed or resigned state. The administration of most conventional antidepressants reduces it. The total duration of the test is $6 \mathrm{~min}$. A total of four batches of five mice each were used for this test, all products were administered by gavage $1 \mathrm{~h}$ before the start of the test.

\subsection{Anxiolytic Activity}

\subsubsection{Tail Suspension Test}

The animal was hanged by its tail $(2 \mathrm{~cm}$ from the end of the box $(50 \times 25 \times 50 \mathrm{~cm})$ for $6 \mathrm{~min}$. When an animal has struggled to make any grappling action and hung with passivity without motion, it is called a suicidal activity and is noted as a time of immobility (only in the last $4 \mathrm{~min}$ were recorded for this test) [45].

\subsubsection{Open Field}

It is used as a test of anxiety, exploration, and locomotion. We orally administered four groups (each with five animals), negative control ( $\mathrm{NaCl} 9 \%)$, positive control treated with bromazepam $(1 \mathrm{mg} / \mathrm{kg})$, and two other groups treated with PCC at 50 and $100 \mathrm{mg} / \mathrm{kg}$, once daily for 21 days was. After sixty minutes of treatment administration, the test was performed by placing each mouse in the central square to explore the arena, and a number of ambulations, rearings, and crossings of central squares were recorded using a digital video camera. The average number of total squares crossed by the mice and crosses of central squares is the number of times the mice entered the central squares with their four legs [46].

\subsubsection{Light and Dark Room}

A wooden box of dimensions $44 \mathrm{~cm} \times 21 \mathrm{~cm} \times 21 \mathrm{~cm}$ is divided into two compartments, a black compartment with cover and a white compartment without cover. The two compartments were separated by a piece of wood with a hole of $7 \mathrm{~cm} \times 7 \mathrm{~cm}$ in the center on the floor surface. The mice were divided into three groups (each consisting of five animals), received a dose of normal saline $(9 \%)$, bromazepam $(1 \mathrm{mg} / \mathrm{kg})$ and PCC (50 and $100 \mathrm{mg} / \mathrm{kg}$ ) once daily for 21 days. After $60 \mathrm{~min}$ of treatment, a 5-min test was performed by placing each mouse in the center of the black box, the time spent in each compartment was recorded by a digital video camera [47].

\subsection{Antioxidant Activity}

The extract tested antioxidant power was evaluated in vitro using two tests, the DPPH test and the reducing power test (FRAP).

\subsubsection{DPPH Test (1, 1-Diphenyl-2-picryhydrozyl)}

The DPPH radical test is performed following the method described by Tepe in 2005 [48]. The test is performed by mixing $975 \mu \mathrm{L}$ of a methanolic solution of DPPH 
$(0.004 \%)$ with $100 \mu \mathrm{L}$ of the sample. The optical density is estimated at $517 \mathrm{~nm}$ after being incubated at laboratory temperature for $30 \mathrm{~min}$. For negative control, the sample is substituted by the methanol. The following Equation (1) determines the inhibition percentage of DPPH:

$$
\mathrm{IP}(\%)=(\mathrm{A} 0-\mathrm{A} / \mathrm{A} 0) \times 100
$$

IP: inhibition percentage; A0: the optical density of the free radical solution (DPPH) in the absence of the extract (negative control); A: absorbance of the free radical solution (DPPH) in the presence of the extract.

\subsubsection{Test of Iron-Reducing Power (FRAP)}

This study was conducted using the Moattar technique [49]; $500 \mu \mathrm{L}$ of phosphate buffer $(0.2 \mathrm{M} ; \mathrm{pH}=6.6)$ and $500 \mu \mathrm{L}$ of $1 \%$ potassium ferricyanide $\left(\mathrm{K}_{3} \mathrm{Fe}(\mathrm{CN})_{6}\right)$ are added to $100 \mu \mathrm{L}$ of the various concentrations of the prepared samples in methanol. After $20 \mathrm{~min}$ of incubation in a water bath at $50{ }^{\circ} \mathrm{C}, 500 \mu \mathrm{L}$ of $10 \%$ TCA solution, $100 \mu \mathrm{L}$ of $\mathrm{FeCl}_{3}(0.1 \%)$ and $0.5 \mathrm{~mL}$ of distilled water are added to the reaction medium. In the absence of the test sample, absorbance is then measured at $700 \mathrm{~nm}$ against a blank comprising all the reagents. The findings are expressed as a 50 percent effective concentration (EC-50) representing the antioxidant concentration needed to reach an absorbance of $0.5 \mathrm{~nm}$.

\subsection{Extract HPLC Analysis}

For the C. carvi extract analysis, An 1260 infinity II high-performance liquid chromatography (HPLC) system (Agilent Technologies, Santa Clara, CA, USA) was used. Fitted with a quaternary pump, the apparatus was coupled with a UV detector. The mobile phase was composed of two solvents, A: 0.1 percent acidified water and B: acetonitrile. A C18 Zorbax eclipse plus $C_{18}$ column $(5 \mu \mathrm{m}, 4.6 \times 150 \mathrm{~mm})$ was used for the separation. The temperature of the column furnace was set at $35^{\circ} \mathrm{C}$. The sample injection volume and flow rates were set at $10 \mu \mathrm{L}(100 \mu \mathrm{g} / \mathrm{mL}$ of sample concentration $)$ and $1 \mathrm{~mL} / \mathrm{min}$. The concentration was calculated according to the following Equation (2), depending on the retention time (RT) and spectral correspondence of each compound:

$$
\text { Concentration }(\mu \mathrm{g} / \mathrm{mL})=(\text { Area }(\text { sample }) / \text { area }(\text { standard })) \times 100
$$

\subsection{Statistical Analysis of Results}

The results of the analysis were expressed using the program Graph Pad Prism 7 for Windows (Microsoft, Albuquerque, NM, USA) as mean \pm standard error of the mean (SEM). A two-way variance analysis (ANOVA) followed by a Dunnett post hoc test was used to conduct data analysis. Significant results were considered when $p<0.05$.

\section{Conclusions}

Conventional treatments used to treat many forms of anxiety and depression have undesirable side effects. Several alternative treatment strategies remain of crucial importance. In this context, medicinal plants are a good source for discovering new remedies for these disorders. In the search for an alternative therapy that is inexpensive and free of side effects, this research has been conducted to study the natural anxiolytic and antidepressant effect of the caraway polyphenolic fraction in anxious and pseudo depressed mice. Our results suggest that the PCC, administered orally, exerts interesting anxiolytic and antidepressantlike effects, particularly at the dose of $50 \mathrm{mg} / \mathrm{kg}$. This study also encourages further studies to reveal the exact mode of action and the limitation of use of this plant.

Author Contributions: Conceptualization I.E.-s. and H.M; methodology, A.A.; software, H.I.; validation, A.G.; formal analysis, A.A. and F.Z.J.; data curation, F.Z.J. and A.G.; writing-original draft preparation, I.E.-s. and H.M.; supervision, A.B. and D.B.; writing-review and editing, O.M.A.K. All authors have read and agreed to the published version of the manuscript. 
Funding: This research was funded by the Deanship of Scientific Research at Princess Nourah bint Abdulrahman University through the Fast-track Research Funding Program.

Institutional Review Board Statement: The study was conducted according to the guidelines of the Declaration of Helsinki, and approved by the Institutional Review Board of the Faculty of Sciences, Fez, Morocco (07\#12/2019/LBEAS and 23 December 2019).

Informed Consent Statement: Not applicable.

Data Availability Statement: Data are available upon reasonable request.

Acknowledgments: The authors are thankful to the Deanship of Scientific Research at Princess Nourah bint Abdulrahman University for the support of this research through the Fast-track Research Funding Program. The authors also send their gratitude to the European project Horizon 2020 MSCARISE-2016-734759-VAHVISTUS.

Conflicts of Interest: The authors declare no conflict of interest.

\section{References}

1. Yoon, J.-H.; Kang, M.-Y.; Jeung, D.; Chang, S.-J. Suppressing Emotion and Engaging with Complaining Customers at Work Related to Experience of Depression and Anxiety Symptoms: A Nationwide Cross-Sectional Study. Ind. Health 2017, 55, 265-274. [CrossRef] [PubMed]

2. Es-Safi, I.; Mechchate, H.; Amaghnouje, A.; El Moussaoui, A.; Cerruti, P.; Avella, M.; Grafov, A.; Bousta, D. Marketing and Legal Status of Phytomedicines and Food Supplements in Morocco. J. Complement. Integr. Med. 2020. [CrossRef] [PubMed]

3. Fajemiroye, J.O.; da Silva, D.M.; de Oliveira, D.R.; Costa, E.A. Treatment of Anxiety and Depression: Medicinal Plants in Retrospect. Fundam. Clin. Pharmacol. 2016, 30, 198-215. [CrossRef] [PubMed]

4. Pan, S.-Y.; Zhou, S.-F.; Gao, S.-H.; Yu, Z.-L.; Zhang, S.-F.; Tang, M.-K.; Sun, J.-N.; Ma, D.-L.; Han, Y.-F.; Fong, W.-F.; et al. New Perspectives on How to Discover Drugs from Herbal Medicines: CAM's Outstanding Contribution to Modern Therapeutics. Evid. Based Complement. Altern. Med. 2013, 2013, 1-25. [CrossRef]

5. Fennane, M.; Rejdali, M. Aromatic and Medicinal Plants of Morocco: Richness, Diversity and Threats; Universite Mohammed V-Agdal Institut Scientifique: Rabat, Morocco, 2016.

6. Fennane, M.; Tattou, M.I. Statistiques et Commentaires sur L'inventaire Actuel de la Flore Vasculaire du Maroc. Bull. Inst. Sci. 2012, 34, 1-9.

7. Watson, M.F. The Genera of the Umbelliferae: A Nomenclator. M. G. Pimenov and M. V. Leonov. London: Royal Botanic Gardens, Kew and Botanical Garden of Moscow University, Russia. 1993. 156 Pp. ISBN 0947643 58 3. £12.00 (Paperback). Edinb. J. Bot. 1995, 52, 92-93. [CrossRef]

8. Johri, R. Cuminum Cyminum and Carum Carvi: An Update. Pharmacogn. Rev. 2011, 5, 63. [CrossRef]

9. Miraj, S.; Kiani, S. Study of Pharmacological Effect of Thymus Vulgaris: A Review. Pharm. Lett. 2016, 8, 315-320.

10. Amaghnouje, A.; Slighoua, M.; Es-safi, I.; El Jaoudi, R.; Elyoubi, A.; Bousta, D.; Grafov, A. Ethnobotanical Survey of Medicinal Plants Used in the Traditional Treatment of Depression and Anxiety in Fez-Meknes Region. Phytothérapie 2020, 18, 220-229. [CrossRef]

11. Dhingra, D.; Chhillar, R.; Gupta, A. Antianxiety-like Activity of Gallic Acid in Unstressed and Stressed Mice: Possible Involvement of Nitriergic System. Neurochem. Res. 2012, 37, 487-494. [CrossRef] [PubMed]

12. Bhutada, P.; Mundhada, Y.; Bansod, K.; Ubgade, A.; Quazi, M.; Umathe, S.; Mundhada, D. Reversal by Quercetin of Corticotrophin Releasing Factor Induced Anxiety-and Depression-like Effect in Mice. Prog. Neuropsychopharmacol. Biol. Psychiatry 2010, 34, 955-960. [CrossRef]

13. Rai, A.; Gill, M.; Kinra, M.; Shetty, R.; Krishnadas, N.; Rao, C.M.; Sumalatha, S.; Kumar, N. Catechin Ameliorates Depressive Symptoms in Sprague Dawley Rats Subjected to Chronic Unpredictable Mild Stress by Decreasing Oxidative Stress. Biomed. Rep. 2019, 11, 79-84. [CrossRef] [PubMed]

14. Ma, Z.; Wang, G.; Cui, L.; Wang, Q. Myricetin Attenuates Depressant-like Behavior in Mice Subjected to Repeated Restraint Stress. Int. J. Mol. Sci. 2015, 16, 28377-28385. [CrossRef]

15. Mudgal, J.; Mallik, S.B.; Nampoothiri, M.; Kinra, M.; Hall, S.; Grant, G.D.; Anoopkumar-Dukie, S.; Davey, A.K.; Rao, C.M.; Arora, D. Effect of Coffee Constituents, Caffeine and Caffeic Acid on Anxiety and Lipopolysaccharide-Induced Sickness Behavior in Mice. J. Funct. Foods 2020, 64, 103638. [CrossRef]

16. Lenzi, J.; Rodrigues, A.F.; de Rós, A.S.; de Castro, B.B.; de Lima, D.D.; Magro, D.D.D.; Zeni, A.L.B. Ferulic Acid Chronic Treatment Exerts Antidepressant-like Effect: Role of Antioxidant Defense System. Metab. Brain Dis. 2015, 30, 1453-1463. [CrossRef] [PubMed]

17. Singh, T.; Kaur, T.; Goel, R.K. Ferulic Acid Supplementation for Management of Depression in Epilepsy. Neurochem. Res. 2017, 42, 2940-2948. [CrossRef] [PubMed]

18. Sasaki, K.; Iwata, N.; Ferdousi, F.; Isoda, H. Antidepressant-Like Effect of Ferulic Acid via Promotion of Energy Metabolism Activity. Mol. Nutr. Food Res. 2019, 63, 1900327. [CrossRef] 
19. Kotwal, S.; Upaganlawar, A.B.; Mahajan, M.; Upasani, C. Protective Effects of Ferulic Acid in Alcohol Withdrawal Induced Anxiety and Depression in Mice. Malays. J. Med. Biol. Res. 2017, 4, 71-78. [CrossRef]

20. Lorigooini, Z.; Nouri, A.; Balali-Dehkordi, S.; Bijad, E.; Dehkordi, S.H.; Soltani, A.; Amini-Khoei, H. Ferulic Acid through Mitigation of NMDA Receptor Pathway Exerts Anxiolytic-like Effect in Mouse Model of Maternal Separation Stress. J. Basic Clin. Physiol. Pharmacol. 2020, 1. [CrossRef]

21. Achenbach, T.M. Manual for the Child Behavior Checklist/4-18 and 1991 Profile; Department of Psychiatry, University of Vermont: Burlington, VT, USA, 1991.

22. Mahendra, P.; Bisht, S. Anti-Anxiety Activity of Coriandrum Sativum Assessed Using Different Experimental Anxiety Models. Indian J. Pharmacol. 2011, 43, 574. [CrossRef] [PubMed]

23. Jung, J.W.; Lee, S. Lee, S. Anxiolytic Effects of Quercetin: Involvement of GABAergic System. J. Life Sci. 2014, 24, 290-296. [CrossRef]

24. Çam, M.; Hışıl, Y.; Durmaz, G. Classification of Eight Pomegranate Juices Based on Antioxidant Capacity Measured by Four Methods. Food Chem. 2009, 112, 721-726. [CrossRef]

25. Ebrahimzadeh, M.A.; Nabavi, S.M.; Nabavi, S.F.; Bahramian, F.; Bekhradnia, A.R. Antioxidant and Free Radical Scavenging Activity of H. Officinalis, L. Var. Angustifolius, V. Odorata, B. Hyrcana and C. Speciosum. Pak. J. Pharm. Sci. 2010, 23, 29-34. [PubMed]

26. Hinneburg, I.; Dorman, H.D.; Hiltunen, R. Antioxidant Activities of Extracts from Selected Culinary Herbs and Spices. Food Chem. 2006, 97, 122-129. [CrossRef]

27. Desrumaux, C.; Risold, P.-Y.; Schroeder, H.; Deckert, V.; Masson, D.; Athias, A.; Laplanche, H.; Le Guern, N.; Blache, D.; Jiang, X.-C. Phospholipid Transfer Protein (PLTP) Deficiency Reduces Brain Vitamin E Content and Increases Anxiety in Mice. FASEB J. 2005, 19, 1-16. [CrossRef] [PubMed]

28. Bilici, M.; Efe, H.; Köroğlu, M.A.; Uydu, H.A.; Bekaroğlu, M.; Değer, O. Antioxidative Enzyme Activities and Lipid Peroxidation in Major Depression: Alterations by Antidepressant Treatments. J. Affect. Disord. 2001, 64, 43-51. [CrossRef]

29. Kuloglu, M.; Atmaca, M.; Tezcan, E.; Ustundag, B.; Bulut, S. Antioxidant Enzyme and Malondialdehyde Levels in Patients with Panic Disorder. Neuropsychobiology 2002, 46, 186-189. [CrossRef] [PubMed]

30. Takeda, H.; Tsuji, M.; Miyamoto, J.; Matsumiya, T. Rosmarinic Acid and Caffeic Acid Reduce the Defensive Freezing Behavior of Mice Exposed to Conditioned Fear Stress. Psychopharmacology 2002, 164, 233-235. [CrossRef] [PubMed]

31. Machado, D.G.; Bettio, L.E.B.; Cunha, M.P.; Santos, A.R.S.; Pizzolatti, M.G.; Brighente, I.M.C.; Rodrigues, A.L.S. Antidepressantlike Effect of Rutin Isolated from the Ethanolic Extract from Schinus molle L. in Mice: Evidence for the Involvement of the Serotonergic and Noradrenergic Systems. Eur. J. Pharmacol. 2008, 587, 163-168. [CrossRef]

32. Priprem, A.; Watanatorn, J.; Sutthiparinyanont, S.; Phachonpai, W.; Muchimapura, S. Anxiety and Cognitive Effects of Quercetin Liposomes in Rats. Nanomed. Nanotechnol. Biol. Med. 2008, 4, 70-78. [CrossRef] [PubMed]

33. Elizalde, N.; Gil-Bea, F.J.; Ramírez, M.J.; Aisa, B.; Lasheras, B.; Del Rio, J.; Tordera, R.M. Long-Lasting Behavioral Effects and Recognition Memory Deficit Induced by Chronic Mild Stress in Mice: Effect of Antidepressant Treatment. Psychopharmacology 2008, 199, 1-14. [CrossRef]

34. Martin, E.I.; Ressler, K.J.; Binder, E.; Nemeroff, C.B. The Neurobiology of Anxiety Disorders: Brain Imaging, Genetics, and Psychoneuroendocrinology. Psychiatr. Clin. N. Am. 2009, 32, 549-575. [CrossRef]

35. Borsini, F.; Meli, A. Is the Forced Swimming Test a Suitable Model for Revealing Antidepressant Activity? Psychopharmacology 1988, 94, 147-160. [CrossRef] [PubMed]

36. López-Rubalcava, C. Strain Differences in the Behavioral Effects of Antidepressant Drugs in the Rat Forced Swimming Test. Neuropsychopharmacology 2000, 22, 191-199. [CrossRef]

37. Detke, M.J.; Lucki, I. Detection of Serotonergic and Noradrenergic Antidepressants in the Rat Forced Swimming Test: The Effects of Water Depth. Behav. Brain Res. 1995, 73, 43-46. [CrossRef]

38. Jamwal, N.S.; Kumar, S.; Rana, A.C. Antidepressant Activity of Methanolic Extract of Foeniculum Vulgare (Fennel) Fruits in Experimental Animal Models. J. Appl. Pharm. Sci. 2013, 3, 65-70.

39. Shahamat, Z.; Abbasi-Maleki, S.; Motamed, S.M. Evaluation of Antidepressant-like Effects of Aqueous and Ethanolic Extracts of Pimpinella Anisum Fruit in Mice. Avicenna J. Phytomed. 2016, 6, 322-328.

40. Karagözler, A.A.; Erdağ, B.; Emek, Y.Ç.; Uygun, D.A. Antioxidant Activity and Proline Content of Leaf Extracts from Dorystoechas Hastata. Food Chem. 2008, 111, 400-407. [CrossRef]

41. Yıldırım, A.; Mavi, A.; Kara, A.A. Determination of Antioxidant and Antimicrobial Activities of Rumex Crispus L. Extracts. J. Agric. Food Chem. 2001, 49, 4083-4089. [CrossRef] [PubMed]

42. Singleton, V.L.; Rossi, J.A. Colorimetry of Total Phenolics with Phosphomolybdic-Phosphotungstic Acid Reagents. Am. J. Enol. Vitic. 1965, 16, 144-158.

43. Amaghnouje, A.; Mechchate, H.; Es-safi, I.; Alotaibi, A.A.; Noman, O.M.; Nasr, F.A.; Al-zharani, M.; Cerruti, P.; Calarco, A.; Fatemi, H.; et al. Anxiolytic, Antidepressant-Like Proprieties and Impact on the Memory of the Hydro-Ethanolic Extract of Origanum Majorana L. on Mice. Appl. Sci. 2020, 10, 8420. [CrossRef]

44. Porsolt, R.D.; Le Pichon, M.; Jalfre, M. Depression: A New Animal Model Sensitive to Antidepressant Treatments. Nature 1977, 266, 730-732. [CrossRef] [PubMed] 
45. Yan, B.; Wang, D.; Xing, D.; Ding, Y.; Wang, R.; Lei, F.; Du, L. The Antidepressant Effect of Ethanol Extract of Radix Puerariae in Mice Exposed to Cerebral Ischemia Reperfusion. Pharmacol. Biochem. Behav. 2004, 78, 319-325. [CrossRef] [PubMed]

46. Walsh, R.N.; Cummins, R.A. The Open-Field Test: A Critical Review. Psychol. Bull. 1976, 83, 482-504. [CrossRef] [PubMed]

47. Malmberg-Aiello, P.; Ipponi, A.; Bartolini, A.; Schunack, W. Mouse Light/Dark Box Test Reveals Anxiogenic-like Effects by Activation of Histamine H1 Receptors. Pharmacol. Biochem. Behav. 2002, 71, 313-318. [CrossRef]

48. Tepe, B.; Daferera, D.; Sokmen, A.; Sokmen, M.; Polissiou, M. Antimicrobial and Antioxidant Activities of the Essential Oil and Various Extracts of Salvia tomentosa Miller (Lamiaceae). Food Chem. 2005, 90, 333-340. [CrossRef]

49. Shams Moattar, F.; Sariri, R.; Yaghmaee, P.; Giahi, M. Enzymatic and Non-Enzymatic Antioxidants of Calamintha Officinalis Moench Extracts. J. Appl. Biotechnol. Rep. 2016, 3, 489-494. 